\title{
„Plemię żmijowe" (Łk 3,7) \\ i pokrewne wypowiedzi w Łk-Dz. \\ Diagnoza sytuacji współczesnych Jezusowi \\ czy kondycji człowieka?
}

\author{
KRZYSZTOF W. MIELCAREK \\ Instytut Nauk Biblijnych, Katolicki Uniwersytet Lubelski Jana Pawła II \\ e-mail: krzysztof.mielcarek@kul.pl \\ ORCID: 0000-0001-8575-7966
}

\begin{abstract}
Summary: The negative phrase: "the brood of vipers" has no equivalent in the OT, neither it is present in the extra-biblical writings. The first evangelist is the one who uses the epithet most often. However, Luke does use it as well (Lk 3:7). The paper is a study of narrative strategies of both Gospel-writers within the context of the OT and the rabbinic literature in order to identify one of the important narrative threads of the third Gospel. Instead of stigmatizing the particular faction of the Israel's religious society, Luke employs the primordial Christian tradition to stress sinfulness of human nature, which in the past resulted in rejecting the good news of Jesus.
\end{abstract}

SŁowa KLucze: potomstwo żmij, pokolenie, żmija i wąż w BH, LXX i NT, grzeszność, teologia Łukasza

KEYwORDs: brood of vipers, generation, viper and snake in BH, LXX and NT, sinfulness, Luke's theology

$\mathrm{O}$

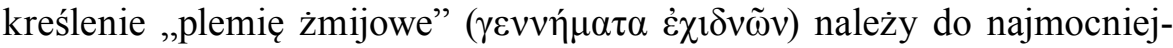
szych negatywnych wypowiedzi, jakie można spotkać w Ewangeliach. Jednakże oddanie całej wewnętrznej dynamiki tego sformułowania wymaga wyboru terminu znacznie odbiegającego od tego, do którego przyzwyczaiło nas większość polskich tłumaczeń. Neutralny sens słowa $\gamma \varepsilon v v \eta ́ \mu \alpha$ odnosi się do jakiegokolwiek gatunku, także ludzkiego, i oznacza po prostu ,,potomstwo”, czyli to, co się urodziło ${ }^{1}$. W stosunku do zwierząt w zależności od procesu związanego z przekazywaniem życia mówi się zwykle o wylęgu lub miocie.

1 Słownik W. Bauera, F.W. Dankera i W. Arndta (A Greek-English Lexicon of the New Testament and Other Early Christian Literature. 3rd ed. [Chicago: University Press 2000] 194) (dalej BDAG)w ten sposób określa termin $\gamma \varepsilon \dot{\varepsilon} \vee \vee \eta \mu \alpha$, „that which is produced or born; child, offspring”. Stąd w źródłach

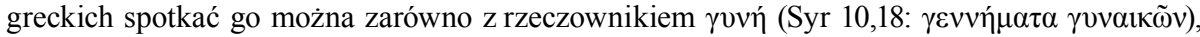

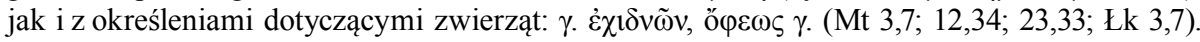


Wprawdzie żmije należą do zwierząt jajorodnych, a więc należy raczej mówić o lęgu żmijowym ${ }^{2}$, ale w tym wypadku określenie biblijne ma najwyraźniej charakter symboliczny i odnosi się do ludzi. Nie należy też zapominać o niezwykle silnym negatywnym ładunku emocjonalnym kontekstu tego zwrotu. Dlatego polska fraza będąca najbliżej wyrażenia greckiego mogłaby brzmieć: „żmijowe pomioty”. W takiej formie brzmi może nieco chropawo i nie do końca precyzyjnie, ale zupełnie dobrze oddaje sens greckiego epitetu.

Dekadę temu amerykański egzegeta C.S. Keener z Filadelfii (Pensylwania) opublikował tekst poświęcony wyrażeniu ,plemię żmijowe” (dosł. „brood of vipers") w Ewangelii św. Mateusza ${ }^{3}$. Natomiast zaledwie dwa lata temu nową propozycję odczytania tej frazy zaproponował M.P. Knowles ${ }^{4}$. Obydwaj zajmują się jednak przede wszystkim kontekstem Ewangelii Mateusza. Przytoczenie ich najważniejszych analiz, a zwłaszcza zarysu hellenistycznego tła tego wyrażenia, jest konieczne do przeprowadzenia rzetelnego zbadania podobnych fraz w dziele Łukaszowym. Stąd kilka akapitów tego artykułu zostanie poświęconych prezentacji dokonań Keenera i Knowlesa. Całość tekstu składać się będzie z sześciu części: 1) ogólnego kontekstu Mt; 2) znaczenia frazy „pomioty żmij” w literaturze rabinicznej; 3) a także hellenistycznej i rzymskiej; 4) wyjaśnienia znaczenia frazy w kontekście pierwszej Ewangelii; 5) specyfika redakcji Łukaszowej wyrażenia o żmijach w powiązaniu z przedstawieniem stronnictwa faryzeuszy; 6) Łukaszowa strategia ukazania grzeszności natury ludzkiej.

\section{Kontekst pierwszej Ewangelii}

Ewangelia Mateusza zawiera kilka podobnych negatywnych określeń, które Jan Chrzciciel, a potem również Jezus, kierują przede wszystkim do religijnych elit Izraela. Pierwszy raz fraza $\gamma \varepsilon v v \eta ́ \mu \alpha \tau \alpha$ $̇ \chi 1 \delta v \tilde{\omega} v$ pojawia się w orędziu Jana Chrzciciela wzywającego Izraelitów do nawrócenia nad Jordanem (Mt 3,7), a następnie zostaje dwukrotnie powtórzona przez Jezusa: najpierw w kontekście nauczania o dobrych owocach (Mt 12,34), a później w ramach krytyki skrybów i faryzeuszy w Jerozolimie (Mt 23,33), jako zwieńczenie niezwykle ostrej w swojej wymowie sekcji składającej się z siedmiu „biada” kierowanych do elit Izraela (23.13.15.16. 23.25.27.29) i siedmiu oskarżeń o hipokryzję (23,13.15.23.25.27.28.29).

2 Pewnym argumentem dodatkowym za określeniem „pomiot” jest również fakt, że samice części gatunków żmij i węży wypuszczają na świat małe bez zewnętrznego składania jaj, co sprawiało, że starożytni długo byli przekonani, iż są to gatunki żyworodne.

3 „«Brood of Vipers» (Matthew 3.7; 12.34; 23.33)”, JSNT 2SA (2005) 3-11 (DOI: 10.1177/ 0142064X05057771).

4 „Serpents, scribes, and Pharisees”, JBL 133/1 (2014) 165-178. 
Przykładów takiej surowej oceny jest więcej. Faryzeusze nazywani są hipokrytami (Mt 15,7 i 22,18), ,ślepymi przewodnikami” (15,14; 23,16.24), „ślepymi głupcami” (23,17; por. $23,19.26)$ oraz ,pobielonymi grobami” $(23,27-29)$. Ich i saduceuszy określa się mianem ,złego i cudzołożnego pokolenia” $(16,4)$. Wszystkie te wypowiedzi świadczą o negatywnym stosunku pierwszego ewangelisty do elit żydowskich, ale nie wyjaśniają, dlaczego został on wyrażony także w odniesieniu do żmij. W komentarzach do Ewangelii Mateusza spotyka się najczęściej ogólnikowe wyjaśnienie, że chodzi tu o negatywną konotację jadowitych gadów, które symbolizują świat zła i przeciwników Boga ${ }^{5}$, ale zdarzają się też bardziej szczegółowe wyjaśnienia ${ }^{6}$.

Domniemane źródła pierwszego ewangelisty, z których mógł on przejąć wspomnianą frazę, nie są jednoznaczne. Mimo że wszystkie przypadki jej użycia przez Mateusza wydają się należeć do materiału źródła Q, tylko pierwszy fragment jest jasno potwierdzony przez paralelną tradycję w Ewangelii Łukasza $(3,7)$. Trzeci ewangelista omija negatywną frazę zarówno w wypowiedzi o dobrych owocach (Łk 6,44-45), jak i w napomnieniach kierowanych do faryzeuszy i znawców Prawa (Łk 11,47-48). Nie wiadomo zatem, czy Łukasz świadomie opuścił tę wypowiedź Jezusa, czy też Mateusz świadomie ją dodał?

\section{Znaczenie „żmijowego pomiotu” we wczesnej literaturze żydowskiej}

Najbardziej naturalnym środowiskiem dla zbadania tła kulturowego wypowiedzi Jana Chrzciciela czy Jezusa są źródła żydowskie. Keener wyraził przekonanie, że ani Talmud, ani inne teksty okołobiblijne w językach semickich nie zawierają niczego, co mogłoby pomóc w zrozumieniu ich sen-

5 Zob. A. Paciorek, Ewangelia wedtug świętego Mateusza. Rozdziaty 1-11 (NKB NT I/1; Częstochowa: Edycja Świętego Pawła 2005) 142. Polski egzegeta traktuje epitet „,potomstwo żmij”" jako przeciwieństwo „potomstwa Abrahama” i wyjaśnia, że chodzi tu o asocjacje z szatanem (Mdr 2,24; Ap 12,9; 20,2; por. J 8,44), a w każdym razie o jakąś „,moc zła i destrukcji”; por. W.D. Davies - D.C. Allison, A Critical and Exegetical Commentary on the Gospel According to Saint Matthew (London; New York: T\&T Clark International 2004) 304; J.M. Boice, The Gospel of Matthew (Grand Rapids, MI: Baker Books 2001) 50.

6 Zob. J. Nolland, The Gospel of Matthew: A Commentary on the Greek Text (Grand Rapids, MI; Carlisle: Eerdmans; Paternoster Press 2005) 142. Australijski uczony traktuje ją jako zapowiedź przyszłego zabójstwa dokonanego na Jezusie, co zapowiadały już wcześniejsze czyny ojców wobec Bożych posłańców. Widzi w niej również wskazanie późniejszej zdecydowanej opozycji między uczniami Pana i żydowskimi frakcjami.

7 Keener („Brood of Vipers”, 4-5) jest przekonany, że inicjatywa redakcyjna leży po stronie Mateusza, a Łukasz nie miał wyraźnej potrzeby rugowania tradycji o faryzeuszach z Q. W.D. Davies i D.C. Allison (A Critical and Exegetical Commentary, 304) odrzucają jednak taką możliwość i przypisują wypowiedź Jana źródłu Q. 
su $^{8}$. Trzeba się zgodzić, że tradycje pochodzące ze źródeł hebrajskich rzeczywiście nie zawierają wyrażenia „potomstwo żmij”, ale nie znaczy to, że są one całkowicie pozbawione ważnego kontekstu dla badań nad tym zagadnieniem. Już w połowie XX w. zwrócono uwagę na znaczenie żmijowo-wężowych konotacji w negatywnym opisie przeciwników ${ }^{9}$, a badania były kontynuowane także i później.

Przede wszystkim warto zdać sobie sprawę, że język hebrajski posługuje się kilkoma określeniami, które nie tylko wskazują węże czy żmije, ale mają również ustaloną negatywną konotację w odniesieniu do wrogów. W BH spotkać można np. określenie kształtach, smoka lub po prostu dużego węża ${ }^{10}$. W literaturze qumrańskiej spotyka się bardzo liczne przykłady zestawienia tego rzeczownika z trucizną (חמת תנינים; por. CD 8,9-10; 19,22[2x]; 1QHa 13,12.29; 4Q216 6,11; 4Q429 f 2,9; 4Q525 f 15,4. 17,4). Podobne wyrażenie zawiera Pwt 32,33 i jest to ważne biblijne skojarzenie $\mathrm{z}$ jadowitymi stworzeniami, ponieważ tam termin ten zestawiony został z rzeczownikiem bezdyskusyjnie oznaczającym jadowite węże i żmije

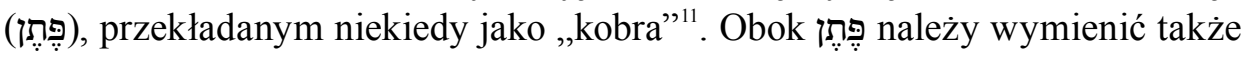

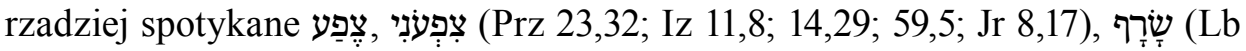

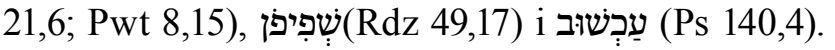

Wyjątkową pozycję w BH ma niewątpliwie rzeczownik נָּח (Rdz 3; Rdz 30,27; 49,17; Wj 4,3; 7,15; Lb 21,6-7.9; Pwt 8,15; Hi 26,13; Ps 58,5; 140,4; Prz 23,32; 30,19; Koh 10,8.11; Iz 14,29; 27,1; 65,25; Jr 8,17; 46,22; Am 5,19; 9,3; Mi 7,17), ale jego funkcja jest szczególna ze względu na oczywiste konotacje mityczne i magiczne ${ }^{12}$. Wystarczy w tym celu wspomnieć o roli, jaką odgrywa on w Rdz 3 lub też miedzianego węża z Lb 21 i $2 \mathrm{Krl} 18^{13}$.

8 Amerykański egzegeta cytuje Talmud babiloński zawierający informację, że żmije cierpią z powodu niezwykle długiej siedemdziesięcioletniej ciąży (b. Bekhorot 8a; por. 8b), ale jego zdaniem jest to jedyny komentarz na temat żmij. Aluzję do ,żmijowego nasienia” w Rdz 3,14-15 uważa za mało prawdopodobną, przede wszystkim ze względu na terminologię. Podobnie teksty u Izajasza (Iz 14,29; por. Iz 30,6) opisują, zdaniem Keenera, raczej węże niż żmije; zob. Keener, „Brood of Vipers”, 6, przyp. 5.

9 M.P. Knowles (,Serpents, scribes, and Pharisees”, 168, przyp. 11) cytuje między innymi J. Carmignaca, „Les elements historiques des «Hymnes» de Qumran”, RevQ 2(1960) 205-222 (219) i J.T. Milika, „4Q Visions de 'Amram et un citation d'Origene”, $R B 79$ (1972) 81-82(13-14).

10 Wprawdzie znaczenie tego terminu jest niejasne, ale konteksty biblijne i pozabiblijne pozwalają na ustalenie przybliżonego sensu. Etymologicznie wywodzi się go najczęściej z hebrajskiej idei

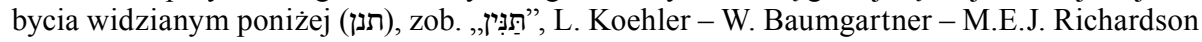
- J.J. Stamm, The Hebrew and Aramaic Lexicon of the Old Testament (electronic ed. Leiden New York: Brill 1999 c1994-1996) (dalej HALOT) 1764.

11 Zob. פתֶֶ,", HALOT (990) podaje znaczenie żmii rogatej, kobry lub innych jadowitych gadów (zob. Pwt 32,33; Hi 20,14.16; Ps 58,5; 91,13; Iz 11,8).

12 Chodzi przede wszystkim o opowiadanie z Rdz 3, ale także etymologiczne związanie tego hebrajskiego rdzenia z wróżbiarstwem i magią; por Rdz 44,5.15; Lb 23,23 itp.

13 J.H. Charlesworth opublikował na ten temat bardzo obszerną monografię; zob. tenże, The Good and Evil Serpent: How a Universal Symbol Became Christianized (Yale: University Press 2010). 
Hebrajskim terminem, który stoi najbliżej greckiego określenia z Ewangelii Mateusza i Łukasza jest אֶפְע identyfikowany niekiedy jako efa pstra ${ }^{14}$ (łac. Echis colorata). Biblia zna kilka przykładów użycia tego rzeczownika. Autor Księgi

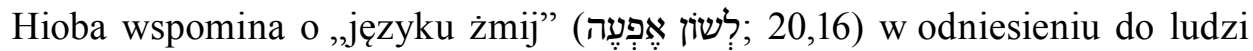

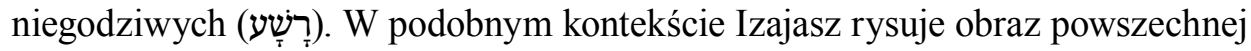
niegodziwości, wzmacniając go sceną, w której pojawiają się pajęczyny i jaja

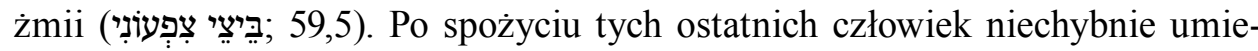
ra, a z pozostawionych jaj wylęgają się żmije (אֶפְֶֶ). W innym miejscu żmija zestawiona jest $\mathrm{z}$ lwami i latającym smokiem $\mathrm{w}$ ramach listy najstraszniejszych zagrożeń dla człowieka $(30,6)$.

U Izajasza gra słów związana $\mathrm{z}$ badanym terminem stała się być może przyczyną skojarzeń obecnych w tekstach z Qumran, ponieważ czasownik פעה: krzyczeć, jęczeć, stękać (zwłaszcza przy porodzie; por. Iz 42,14), ma formę cohortativu identyczną z rzeczownikiem żmija. Tym samym forma imperfectum „będę jęczeć” jest homonimem rzeczownika „żmija”.

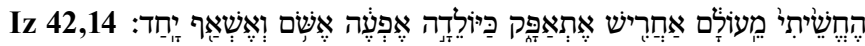

Iz 42,14 „Milczałem od długiego czasu, w spokoju wstrzymywałem siebie, teraz jakby rodząca zakrzyknę, dyszeć będę z gniewu, zabraknie mi tchu” (BT).

Gdyby cohortativus tego czasownika potraktować jednak jak rzeczownik, można by go przetłumaczyć: „rodząca żmiję”, co mogłoby oznaczać samicę żmii wydającą na świat swoje potomstwo lub pełen horroru obraz, w którym kobieta rodzi żmiję. Ta nieco przerysowana możliwość interpretacyjna została najprawdopodobniej wykorzystana w Qumran.

Użycie terminu w zwojach qumrańskich nie jest ani jednoznaczne, ani łatwe do zrozumienia, ale ich analiza może, przynajmniej do pewnego stopnia, naświetlić kontekst wypowiedzi ewangelicznych Jana i Jezusa. W zbiorze tekstów z Qumran znajduje się kilka hymnów (Hôdayôt), w których odnaleźć można między innymi skargę Nauczyciela Sprawiedliwości na swoich przeciwników, którzy atakują go bezpardonowo, a nawet czyhają na jego życie. Fragment hymnu 11. zapisanego w 10. kolumnie rękopisu zawiera bardzo interesujące sformułowanie ${ }^{15}$ :

14 Jadowity wąż z rodziny żmijowatych. Wypowiedzi Jana i Jezusa nie można jednak traktować w kategoriach konkretnego gatunkowego wskazania. Chodzi raczej o ogólną grupę groźnych, jadowitych gadów; zob. ,אפְְע", $B D A G, 419$.

15 Niestety poszczególne wydania $1 \mathrm{QHa}$ i jej tłumaczenia różnie numerują tekst, stąd różnice w oznaczeniu wersetów. $Z$ uwagi przedstawienie większej palety znaczeń tekstu oryginalnego autor postanowił odwołać się również do przekładów angielskich. 
למזורות יבקעו אפעה ושוא בהתרומם גליהם. :1QHa 10,29-30

Do gwiazd wylatują ${ }^{28}$ pustka i próżnia, gdy wznoszą się ich fale ${ }^{16}$.

Wickedness and fraud burst forth to the stars ${ }^{30}$ when their waves pile high ${ }^{17}$.

Right up to the stars burst ${ }^{28}$ emptiness and deceit when their waves heave upwards ${ }^{18}$.

Tekst ma niewątpliwie charakter żywej metafory, ponieważ chwilę wcześniej mówi się o wojennym orężu, potężnych falach i huraganie, zestawiając je z działaniami wrogów autora. Jednakże nawet jeżeli hebrajską frazę odczyta się dosłownie, można w niej widzieć symbol zła i podłości.

W hymnie 13. zapisanym w 11. kolumnie tekstu, skarżący się na swoją sytuację autor porównuje działania atakujących go do kobiety, w której poczyna się dziecko. Wers 12.(13.) przynosi jednak niespodziewany, dramatyczny obraz:

1QHa והרית אפעה לחבל נמרץ ומשברי שחת לכול מעשי פלצות 11,13

${ }^{12}[\ldots]$ I wėżowej ciąży towarzyszy przeszywający ból i grobowym łonom wszelkie potworne dzieła.

${ }^{13}[\ldots]$ But she that is pregnant with wickedness experiences excruciating pain, and the crashing waves of the pit for all works of terror ${ }^{19}$.

${ }^{12}[\ldots]$ And she who is pregnant with a serpent is with a racking pang; and the breakers of the pit result in all deeds of terror ${ }^{20}$.

Porównanie tłumaczeń pokazuje, że tekst hebrajski może być różnie interpretowany. Wise i Abeg starają się kontynuować myśl autora o ludzkiej ciąży, stąd rzeczownik ,żmija” jest tłumaczony symbolicznie „podłość” (,wickedness”). Natomiast w polskim thumaczeniu rzeczownik zachowano w jego podstawowym znaczeniu, lecz zdanie zostało zamienione na wtrącenie porównujące wcześniejsze okoliczności towarzyszące poczęciu człowieka z momentem zapłodnienia żmii. Obydwa tłumaczenia próbują poradzić sobie z uzgodnieniem kontekstu $z$ niespodziewanym rzeczownikiem. Tekst tłumaczony dosłownie sugerowałby bowiem, że autor porównuje swoją sytuację do kobiety, która poczęła żmiję. Takie thumaczenie proponuje F. García Martínez i E. Tigchelaar (,she who is pregnant with a serpent" $)^{21}$.

16 Tłumaczenie polskie tekstów za P. Muchowski, Rękopisy znad Morza Martwego. Qumran, Wadi Murabba'at i Nachal Chewer (Kraków: Enigma Press 2000) 68-69.

17 Tłumaczenie angielskie za M.O. Wise - M.G. Abegg, jr. - E.M. Cook, The Dead Sea Scrolls. A New English Translation (San Francisco, Ca: Harper Collins 1996, 2005, electronic edition).

18 F. García Martínez - E. Tigchelaar, The Dead Sea Scrolls Study Edition (Translations) (Leiden - New York: Brill 1997-1998) 1,161.

19 Wise - Abegg, jr. - Cook, The Dead Sea Scrolls.

20 García Martínez - Tigchelaar, The Dead Sea Scrolls Study Edition, 165

21 The Dead Sea Scrolls Study Edition (Translations) (Leiden - New York: Brill 1997-1998) 1,165, por. M. Delcor, Les hymnes de Qumran (Hodayot): Texte hébreu, introduction, traduction, commentaire (Paris: Letouzey et Ane 1962) 114; S. Mędala, „List do arcykapłana z Qumran (4QMMT) a «jad żmijowy» faryzeuszów”, CT 64/3 (1994) 68. Warto jednak zaznaczyć obserwację M.P. Knowlesa („Serpents, Scribes, and Pharisees”, 169, przyp. 14), że wielu uczonych 
Ten dramatyczny obraz kontynuowany jest kilka wersetów dalej:

ויפתחו שערי שאול לכול מעשי אפעה . 1QHa 11,18

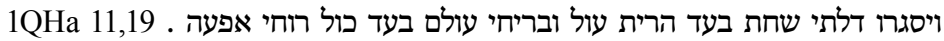

${ }^{17}$ [...] Bramy [szeolu] otwierają się [dla wszystkich] dziel węża. ${ }^{18}$ I zamykają się bramy zatracenia za płodem (?) bezprawia i wieczne rygle za wszystkimi duchami wėza.

${ }^{18}[\ldots]$ and the gates [of Sheol] open [for all] the works of wickedness. ${ }^{19}$ Then the doors of the pit shut up the one who is pregnant with injustice, and the eternal bars shut up the spirits of wickedness.

${ }^{17}$ and the gates of [Sheol] open [for all] the deeds of the serpent. ${ }^{18}$ And the doors of the pit close upon the one expectant with injustice, and everlasting bolts upon all the spirits of the serpent ${ }^{22}$.

Wise konsekwentnie trzyma się interpretacji symbolicznej, zamieniając „żmiję" na „niegodziwość/podłość”. Natomiast inni tłumacze pozostawiają pierwotne znaczenie terminu: „wąż/żmija”. Dosłowne tłumaczenie pozwala na interpretację, że w przekonaniu rozgoryczonego autora z Qumran całe zło skończy się ostatecznie w Szeolu, a uzasadnieniem takiego końca jest fakt, że są one „czynami żmii” (מעשי אפעה). Wszystkie zaś siły duchowe, które mu służą są „duchami żmii”" (רוחי אפעה).

Podsumowując, można stwierdzić, że tradycja qumrańska i niewielka liczba fragmentów obecnych w BH posługują się obrazem żmii i często kierują uwagę czytelnika ku sferze zła ${ }^{23}$. Szczególnie cenny jest przypadek qumrańskiego hymnu, w którym podłe zamysły i działania zostały skojarzone ze stanem ciąży. Efektem tej ciąży będzie jednak nie normalny ludzki potomek, lecz żmija.

Nowy aspekt wykorzystania semickiego tła zaproponował ostatnio M.P. Knowles. Jego zdaniem trzeba wziąć pod uwagę nie tylko istniejące biblijne i okołobiblijne tradycje, ale również pewne zwyczaje towarzyszące starożytnym polemikom. Zdaniem amerykańskiego uczonego należą do nich uszczypliwe asocjacje oparte między innymi na paronomazji (metatezie). Stąd hebrajskie

nie przyjmuje dosłownego tłumaczenia tej frazy i opowiada się za znaczeniem abstrakcyjnym podłość/niegodziwość (Parry, Tov).

22 García Martínez - Tigchelaar, The Dead Sea Scrolls Study Edition, 165.

23 J.H. Charlesworth („John the Baptizer and the Dead Sea Scrolls”, The Bible and the Dead Sea Scrolls: The second Princeton Symposium on Judaism and Christian Origins. Volume three [red. J.H. Charlesworth] [Waco, Tx: Baylor University Press 2006] 9) jest przekonany, że przedstawione tu tradycje $\mathrm{z}$ Qumran stanowią podstawowe tło wypowiedzi o żmijach w tradycji synoptycznej i stały się inspiracją do epitetu zawartego w Q/Mt. Jego stanowisko słusznie zostało jednak odrzucone przez S.E. Portera, który konstatuje: ,Just because the Qumranites criticized the Pharisees and Sadducces and they mention «vipers» does not mean that there is a correlation with John's statements.”; zob. tenże: „Was John the Baptist a Member of the Qumran Community? Once More", Christian Origins and Hellenistic Judaism (red. S.E. PorterA. Pitts; E-Books Online Collection: Brill 2013) 288, Chapter DOI: 10.1163/9789004236394_012 E-ISBN: 9789004236394. 
rdzenie oznaczające dwie frakcje religijne z czasów Jezusa ספרים i פרושים można było skojarzyć z rzeczownikiem reprezentującym jadowitego węża שרף ספר 24 . Słabością tego opracowania jest jednak brak ścisłego kontekstu semickiego w Ewangelii, która w obecnym kształcie jest częścią świata hellenistycznego $\mathrm{i}$, co autor sam przyznaje, spekulatywny charakter takiej interpretacji ${ }^{25}$.

\section{Znaczenie „żmijowego pomiotu" w kulturze hellenistycznej i rzymskiej}

Stosunkowo wąska ewidencja tekstów hebrajskich usprawiedliwia odwołanie się do szerszego kontekstu kultury śródziemnomorskiej, czyli do tekstów greckich i łacińskich ${ }^{26}$.

Słownik języka greckiego H.G. Liddella i R. Scotta ${ }^{27}$ nie podaje zbyt wielu przykładów rzeczownika ह̌ $\chi 1 \delta v \alpha$. O żmijach wspomina Herodot w V w. przed Chr., a także Platon (Symposium 218a) i Arystoteles (Mirabilia $846^{\mathrm{b}} 18$ ), zwykle akcentując realne zagrożenie dla życia człowieka. Ajschylos (Choephori 249) i Sofokles (Antigone 531) używają go w odniesieniu do zdradzieckiej żony lub przyjaciela. Zgorzkniały najwyraźniej Secundus Milczący cynik żyjący w II w.

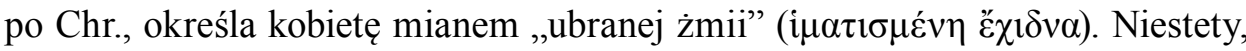
w żadnym tekście poza Ewangeliami nie spotyka się frazy $\gamma \varepsilon v v \eta ́ \mu \alpha \tau \alpha \dot{\varepsilon} \chi 1 \delta v \tilde{\omega} v$.

Termin $\gamma \varepsilon v v \eta ́ \mu \alpha$ występuje w Biblii Greckiej tylko dwa razy i zawsze w odniesieniu do ludzkiego potomstwa bez żadnych negatywnych konotacji. Księga Sędziów $(1,10)$ wspomina o potomkach Enaka, a Księga Syracha $(10,18)$

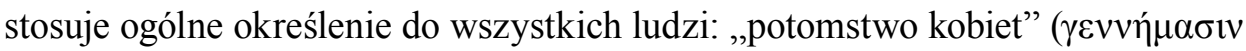

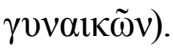

Jedną z możliwości odczytania frazy „potomstwa żmij” jest potraktowanie jej jako tzw. dopełniacza jakości zwanego również hebrajskim. Pismo Święte zawiera liczne przykłady tego rodzaju składni wskazującej na bezpośredni związek rzeczownika zwanego nomen regens np. syn z nomen rectum np. światłość, ciemność, śmierć itp. W tym kluczu wyrażenie to oznaczałoby ludzi, którzy mają związek ze żmijami, przy czym związek ten nie miałby oczywiście charakteru fizycznego, ale raczej metaforyczny. Chodziłoby zatem o posiadanie cech

24 Tego rodzaju techniki stosowano powszechnie na Bliskim Wschodzie. Przykładem inwektywy opartej na podobnych zasadach jest tytuł znienawidzonego Seleucydy, Antiocha IV Epifanesa,

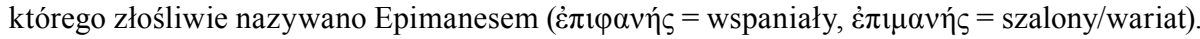

25 Zob. „Serpents, scribes, and Pharisees”, 174.

26 Do takich obrazów w literaturze klasycznej odwołuje się np. D.A. Hagner, Matthew 1-13 (WBC 33A; Dallas: Word Incorporated 2002) 50.

27 Zob. H.G. Liddell - R. Scott - H.S. Jones - R. McKenzie, A Greek-English Lexicon (Oxford - New York: Clarendon Press, Oxford University Press 1996) 748. 
przypisywanych żmijom ${ }^{28}$. Problemem w tym wypadku jest jednak rzadkość użycia terminu $\gamma \varepsilon v v \eta ́ \mu \alpha$.

Znacznie bardziej obiecującym tropem jest przekaz zawarty w Historii Herodota (3.109), który odwołuje się do przekonań na temat zachowania żmij w Arabii. Według greckiego historyka samice żmii pozbawiają życia swoich partnerów bezpośrednio po zapłodnieniu, ale tracą one $\mathrm{z}$ kolei życie w wyniku działań swojego potomstwa, co jest rodzajem naturalnej sprawiedliwości. Młode żmii, zdaniem Herodota, torują sobie bowiem drogę na świat, przegryzając się przez powłoki ciała swojej matki i przyczyniają się w ten sposób do jej śmierci. Trudno ocenić zasięg tych wyobrażeń w starożytności, ale mogły one wpłynąć na negatywne postrzeganie żmij w ogólności. W każdym razie powtarzają je jeszcze niejaki Elian Klaudiusz w III w. po Chr. (De Natura Animalium 1.24), Pliniusz (Historia naturalis 10.169-170) oraz Plutarch (Moralia 567F), a Filostrates wyraża przekonanie, że takie zachowanie żmij jest powszechnie znane (Vita Apollonii 2.14) ${ }^{29}$.

Świadectwa starożytnych autorów nabierają szczególnego znaczenia w zestawieniu z przekonaniem, że uśmiercenie rodziców (parenticidium) należało do najcięższych zbrodni ${ }^{30} \mathrm{i}$ było ścigane przez boginie zemsty Erynie/Furie ${ }^{31}$. Zabójstwo bliskich przywołuje bowiem na myśl ważny temat tradycji synoptycznej, dotyczący postawy słuchaczy Jezusa i ich przodków. W ramach nauczania Jezusa parokrotnie pojawia się zarzut, że zarówno przodkowie, jak i obecni oponenci Bożych planów są mordercami. W dawnych czasach zabijali oni posłańców Boga (Łk 11,47-49; 13,34; Dz 7,52), a w niedługim czasie przyczynią się do śmierci Jego Syna (Łk 9,22; 13,31; 18,33; 20,14-15; Dz 3,15; ) i będą nastawać na życie uczniów Chrystusa (Dz 21,31; 22,22; 23,12.14). Wszyscy oni, pozostając dziećmi Abrahama i Jakuba, stają się przez to mordercami swoich krewnych.

\section{Mateuszowe rozumienie „potomstwa żmij”}

Jak podkreśla Keener, pierwszy i trzeci ewangelista poświęcają wiele miejsca faryzeuszom, co dobrze oddaje statystyka słownictwa (Mt 29x; Mk 11x; Łk 26x).

28 Zob. W.D. Davies - D.C. Allison, A Critical and Exegetical Commentary on the Gospel According to Saint Matthew (London - New York: T\&T Clark International 2004) 304.

29 Szerzej na temat przekazów starożytnych o wężach i żmijach zob. Keener, „Brood of Vipers”, 7-8.

30 Amerykański egzegeta wśród świadków takiego przekonania wymienia między innymi Sofoklesa, Korneliusza Neposa, Diodora Siculusa, Dionizego z Halikarnasu, Senekę, Epikteta, Plutarcha, Marka Aureliusza i innych; zob. Keener, „Brood of Vipers”, 8, przyp. 10.

31 Lista starożytnych autorów wymienianych przez Keenera w tym kontekście jest długa: Eurypides, Sofokles, Tibullus, Owidiusz, Dios Chrysostom, Stacjusz, Silius Italicus. W innym przypadku kojarzono je z Gorgonami (Pindar, Owidiusz, i Statius) lub innymi stworzeniami budzącymi powszechną grozę (Pauzaniasz, Apollodorus, Filostratus); zob. Keener, „Brood of Vipers", 8, przyp. 10. 
Obok nich, ale w mniejszym stopniu, wymienia się także skrybów i saduceu$\mathrm{szy}^{32}$. Nawet uwzględniając różnicę objętości poszczególnych Ewangelii, jest oczywiste, że dwaj późniejsi synoptycy skupiają swoją uwagę na stronnictwach religijnych, a zwłaszcza na faryzeuszach, daleko bardziej niż Marek. Na tym jednak podobieństwo się kończy.

Mateusz najwyraźniej uzupełnia tradycję Markową wzmiankami o faryzeuszach z wykorzystaniem Q (por. Mt 3,7; Łk 3,7). Jego redakcja niesie zdecydowany przekaz krytyczny. Już w pierwszej scenie $(3,7)$ to właśnie faryzeusze zostają nazwani „potomstwem żmij”, a następnie ich sprawiedliwość zostaje przedstawiona jako niewystarczająca do wejścia do królestwa Bożego $(5,20)$. Faryzeusze krytykują Jezusa za przebywanie wśród celników $(9,11$; por. Mk 2,16) i oskarżają Go o działanie w mocy diabła $(9,34 ; 12,24$ por. Mk 3,22). Krytykują zachowanie uczniów Jezusa $(12,2$; por. Mk 2,24) i już na początku Jego działalności planują Jego usunięcie $(12,14$; por. Mk 3,6$)$. Gorszą się wykładnią Jezusa na temat legalnej czystości (15,11-12; SMt!), żądają znaku (16,1; por. Mk 8,11), ich postawa jest nazwana mianem „kwasu” (16,6.11[SMt]; por. Mk 8,15), wystawiają Jezusa na próbę (19,3; por. Mk 10,2 i 22,34 [SMt]) lub chcą go przyłapać na jakiejś niezręcznej wypowiedzi $(22,15$; por. Mk 12,13). Do nich Jezus kieruje wielokrotne „biada” i nazywa ich hipokrytami oraz ślepcami (23,13-31 [SMt;Q?]). Knują przeciw Jezusowi nawet po Jego śmierci, wietrząc oszustwa ze strony apostołów (27,62-66).

Tak negatywny obraz faryzeuszy dobrze uzupełniają dwie wypowiedzi Jezusa, powielające napomnienie Jana Chrzciciela (Mt 12,34, 23.33). Według pierwszego ewangelisty faryzeusze i ich zwolennicy są synonimem wrogów, którzy angażują się po stronie ciemności, by uniemożliwić Jezusowi dokończenie misji ${ }^{33}$. Należą do pokolenia, które wzorem Nauczyciela Sprawiedliwości można nazwać tymi, którzy rodzą żmije ${ }^{34}$.

\section{5. Łukaszowa redakcja wyrażenia o „potomstwie żmij” i tradycji o faryzeuszach}

Trzeci ewangelista, mimo że wykorzystuje te same podstawowe źródła (Mk i Q), nie wybiera teologicznej opcji Mateusza. Widać to już w tekście o orędziu Jana Chrzciciela, który tylko pozornie jest paralelny do pierwszej Ewangelii (Łk 3,7). Podczas gdy Mateuszowy Jan Chrzciciel swój surowy osąd kieruje jednoznacznie

32 Zob. Keener, „Brood of Vipers”, 5.

33 Por. D.A. Hagner, Matthew 14-28 ([WBC 33b] Dallas: Word Incorporated 2002) 672; M. Simonetti, Matthew 14-28 (ACCoSNT 1b) (Downers Grove, Ill: InterVarsity Press 2002) 181.

34 Zob. paragraf 2. niniejszego artykułu. 
do faryzeuszy i saduceuszy (Mt 3,7), krytyka według Łukasza ma charakter

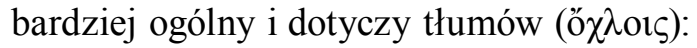

\begin{tabular}{|c|c|}
\hline 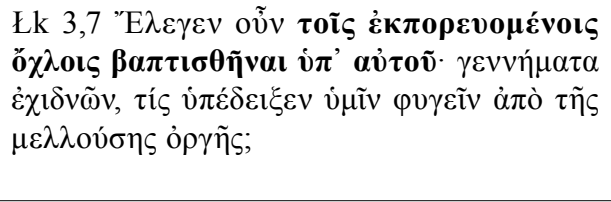 & 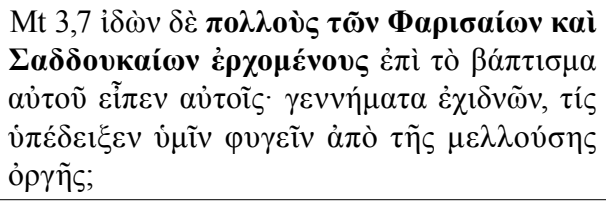 \\
\hline $\begin{array}{l}\text { Łk 3,7 Mówił więc do tlumów, które wycho- } \\
\text { dzily, żeby przyjąć chrzest od niego: „Plemię } \\
\text { żmijowe, kto wam pokazał, jak uciec przed } \\
\text { nadchodzącym gniewem?” }\end{array}$ & $\begin{array}{l}\text { Mt } 3,7 \text { A gdy widział, że przychodzi do } \\
\text { chrztu wielu spośród faryzeuszów i sadu- } \\
\text { ceuszów, mówił im: „Plemię żmijowe, kto } \\
\text { wam pokazał, jak uciec przed nadchodzącym } \\
\text { gniewem?” }\end{array}$ \\
\hline
\end{tabular}

Dzięki temu prostemu zabiegowi redakcyjnemu wymowa wykorzystanej tradycji staje się odmienna. Nie chodzi już o pojedynczą grupę zadufanych w sobie elit Izraela, ale o wszystkich zgromadzonych ${ }^{35}$.

Jednocześnie jednak generalizacja wypowiedzi Jana ma także charakter łagodzący. Skoro chodzi o cały lud słuchający Janowej nauki i przystępujący do chrztu, epitet o żmijach nie oznacza już złośliwego, świadomego przeciwstawiania się Bożym planom, jak to miało miejsce w Qumran ${ }^{36}$. Nie jest też napiętnowaniem jednej konkretnej kasty, co widać u Mateusza. Jest raczej surową diagnozą stanu duchowego ludzi obecnych nad Jordanem ${ }^{37}$.

Trzeci ewangelista świadomie rezygnuje ze strategii piętnowania określonych środowisk religijnych Izraela. Dotyczy to zwłaszcza faryzeuszy. Waldemar Rakocy dogłębnie zbadał tę narracyjną strategię Łukasza w obydwu tomach jego dzieła $^{38}$. Z szczegółowych analiz lubelskiego uczonego wynika, że autor Łk-Dz wyraźnie dystansuje się od optyki zarówno Marka, jak i Mateusza.

$\mathrm{W}$ przypadku synoptycznego porównania $\mathrm{z}$ drugim ewangelistą można stwierdzić, że Łukasz wprowadza faryzeuszy do swojej narracji nawet tam, gdzie Marek na ich temat milczy (Łk 5,7.30). Niekiedy czyni ich jedynymi rozmówcami Jezusa $(5,33)$, a w innych miejscach głównymi ${ }^{39}$. Łukasz łagodzi negatywne nastawienie faryzeuszy do Jezusa widoczne u Marka, usuwając ich

35 F. Bovon - H. Koester, Luke 1: A Commentary on the Gospel of Luke 1:19:50, Hermeneia a Critical and Historical Commentary on the Bible (Minneapolis, MN: Fortress Press 2002) 122; F. Mickiewicz, Ewangelia wedtug świętego Łukasza, rozdziaty 1-11. Wstęp, przektad z oryginatu, komentarz (NKB III/1; Częstochowa: Edycja Świętego Pawła 2011) 217.

36 Zob. analizę tekstów w paragrafie 2.

37 J. Nolland deklaruje otwarcie: „Luke's interest, however, will be in the universal need for repentance (Luke 11:29; 13:1-5; cf. 11:13)"; zob. tenże, Luke 1:1-9:20 (WBC 35A; Dallas: Word, Incorporated 2002) 147.

38 Obraz i funkcja faryzeuszy $w$ dziele. Lukaszowym (Łk-Dz): studium literacko-teologiczne (Lublin: RW KUL 2000).

39 Rakocy, Obraz i funkcja faryzeuszy, 52-54. 
bezpośrednie oskarżenia o przebywanie Jezusa wśród grzeszników (Mk 2,16) i pretensje dotyczące zachowania uczniów $(2,24)$. W relacji trzeciej Ewangelii faryzeusze oczekują przede wszystkim wyjaśnienia i kierują pytania do samych uczniów (Łk 5,30; 6,2). Znacznie bardziej życzliwy jest także stosunek Jezusa do faryzeuszy. Jego nauczanie ma na celu pozyskanie ich dla królestwa, a nie potępienie $(5,27-32 ; 6,1-5)$. Tę samą tendencję widać również w jerozolimskiej części narracji (19,39-40 i 20,20-26), gdzie brakuje faryzeuszy w gronie spiskujących przeciw Jezusowi ${ }^{40}$.

Materiał Q (Mt) również został przez Łukasza złagodzony. Dlatego w trzeciej Ewangelii faryzeusze nie przypisują Jezusowi działania w Nim mocy nieczystych i nie żądają od Niego znaku (11,15.16.29 - „niektórzy”, „inni”, „to pokolenie”). Jedyną poważniejszą konfrontację $\mathrm{z}$ faryzeuszami trzeci ewangelista rysuje w Łk 11,37-54 (redakcja Q). Tekst wprowadzony perykopą o wizycie w domu faryzeusza (w. 37-38) jest jednak i tak o wiele łagodniejszy w swojej wymowie niż paralelna do niego tradycja Mateuszowa (23,13-36). Jak podkreśla W. Rakocy, ocena Jezusa w tej części trzeciej Ewangelii ma przede wszystkim charakter etyczny i odnosi się do nauczania samych faryzeuszy, a przy okazji świadomie przenosi ciężar oskarżenia na stronnictwo uczonych w Piśmie. Warto też podkreślić, że Łk 11,53-54 jest jednocześnie ostatnim tekstem, w którym faryzeusze pełnią rolę otwartych przeciwników Jezusa ${ }^{41}$.

\section{Uniwersalizacja upadku przez redakcję synoptycznej tradycji}

Obok wyłączenia faryzeuszy z grona bezpośrednich przeciwników Jezusa Łukasz stosuje jeszcze jeden redakcyjny zabieg, a mianowicie generalizację sytuacji duchowej ludu Izraela. Kluczową kwestią są tu teksty zawierające określenie „to

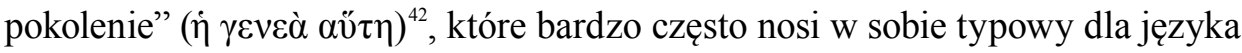

40 Rakocy, Obraz i funkcja faryzeuszy, 53 i 61.

41 Rakocy, Obraz i funkcja faryzeuszy, 98. Na temat Łukasza motywacji łagodzenia tradycji o faryzeuszach zob. też D.P. Moessner, ,The «Leaven of the Pharisees» and «this generation»: Israel's rejection of Jesus according to Luke", JSNT 34(1988) 21-46.

42 Szwedzki egzegeta E. Lövestam poświęcił temu zagadnieniu w Nowym Testamencie całą monografię; zob. tenże, Jesus and «This Generation»: A New Testament Study (Stockholm: Almqvist \& Wiksell International 1995). Według niego wyrażenie to należy niemal wyłącznie do tradycji synoptycznej i zostało najprawdopodobniej oparte na tekstach podobnych do $\mathrm{Wj}$ 17; Pwt 1,35; 32,5.20; Ps 95, które odnoszą się do pokolenia z okresu pustyni. Był on pierwotnie odnoszony nie tyle do jakiejś konkretnej grupy, ile raczej do buntowniczej postawy ludzi wobec Boga i jego posłańców. Baza historyczna przekazów ewangelicznych jest prawdopodobna i może wyjaśnić chrystologiczny i soteriologiczny aspekt tego wezwania; zob. tamże 102-103. Mimo że praca jest problematyczna pod względem metodologicznym i wiele szczegółowych stwierdzeń trudno przyjąć, ogólne wnioski Lövestama wydają się właściwe. 
hebrajskiego aspekt pejoratywny ${ }^{43}$. Fraza ta przyjmuje niekiedy bardziej rozbudowaną i jednoznacznie negatywną formę. Tabela poniżej prezentuje rozkład synoptyczny użycia frazy $\dot{\eta} \gamma \varepsilon v \varepsilon \dot{\alpha} \alpha u ̃ \tau \eta:$

\begin{tabular}{|c|c|c|c|}
\hline Mt & $\mathbf{L k}$ & $\mathrm{Mk}$ & Forma alternatywna w miejscu paralelnym \\
\hline \multirow[t]{3}{*}{11,16} & 7,31 & & \\
\hline & & & 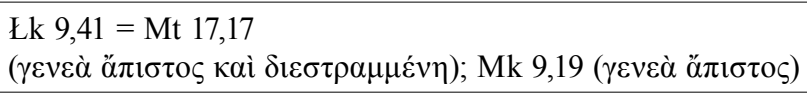 \\
\hline & 11,29 & $8,12(2 x)$ & 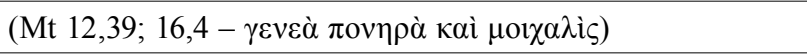 \\
\hline 12,41 & 11,30 & & \\
\hline \multirow[t]{3}{*}{12,42} & 11,31 & & \\
\hline & 11,32 & & \\
\hline & 11,50 & & \\
\hline \multirow[t]{2}{*}{12,45} & & & 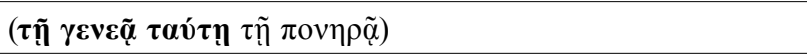 \\
\hline & & 8,38 & 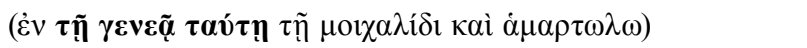 \\
\hline \multirow[t]{3}{*}{23,36} & 11,51 & & \\
\hline & 12,29 & & \\
\hline & 17,25 & & \\
\hline 24,34 & 21,32 & 13,30 & \\
\hline
\end{tabular}

Zestawienie pokazuje jednoznacznie kilka istotnych zjawisk: 1) trzeci ewangelista najchętniej odwołuje się do badanej frazy; 2) tylko raz decyduje się ją rozbudować do bardziej negatywnej postaci, podobnie jak Mateusz za Pwt 32,5

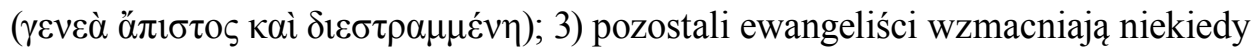
wymowę tej negatywnej frazy dodatkowymi epitetami.

Ogólne obserwacje nie oddają w pełni tendencji redakcyjnej Łukasza, a tym samym zawartości jego teologicznego przekazu. W tym celu zostanie podjęta analiza wybranych fragmentów w zestawieniu synoptycznym (Mt 11,16; 12,41-42; 23,36; 24,34 Łk 7,31; 11,29-32.50-51; 17,25; 21,32; Dz 2,40).

43 Najlepszym przykładem może być hebrajskie określenie obecnego okresu i przyszłego, w którym Bóg doprowadzi do zwycięstwa dobra nad złem. Wiek obecny jest nazywany „tym wiekiem” (hebr. (עלרָם הַ) z wyraźną negatywną konotacją; por. P. Joüon - T. Muraoka, A Grammar of

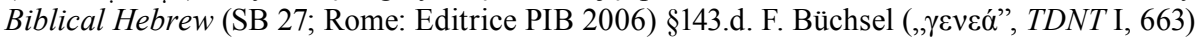
powołuje się na komentarz A. Schlattera do Ewangelii Mateusza z 1929 r., który w greckiej frazie o tym pokoleniu dostrzega rabinackie haddôr hazze ${ }^{h}$. Jego źródeł można dopatrywać się również w tradycjach starotestamentowych. W opowiadaniu o Noem jest on przedstawiony jako

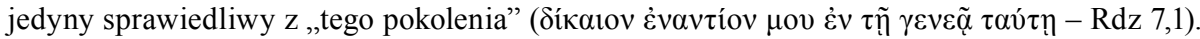
Psalmista, mówiąc o powszechności grzechu, używa podobnego określenia (Ps 11,8 [LXX]; Ps 94 [LXX]); por. Jr 8,3. 


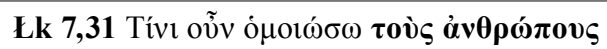

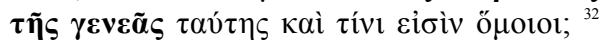

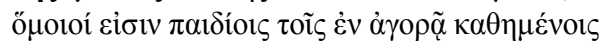

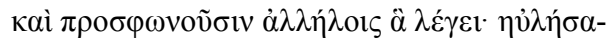

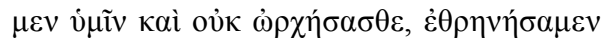

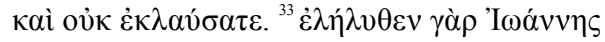

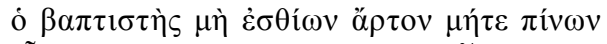

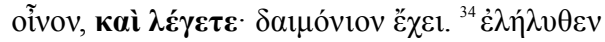

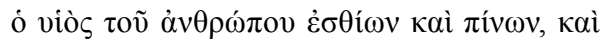

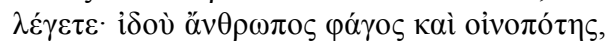

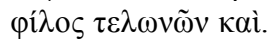

Lk 7,31 Z kim więc mam porównać ludzi tego pokolenia? Do kogo są podobni? ${ }^{32}$ Podobni są do dzieci, które przebywają na rynku i głośno przymawiają jedne drugim: „Przygrywaliśmy wam, a nie tańczyliście; biadaliśmy, a wyście nie płakali”. ${ }^{33}$ Przyszedł bowiem Jan Chrzciciel: nie jadł chleba i nie pił wina; a wy mówicie: „Zły duch go opętał”. ${ }^{34}$ Przyszedł Syn Człowieczy: je i pije; a wy mówicie: „Oto żarłok i pijak, przyjaciel celników i grzeszników”.

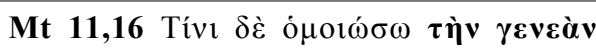

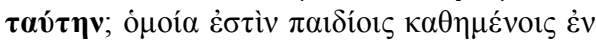

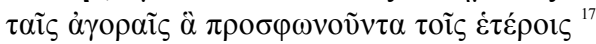

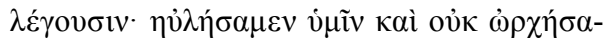

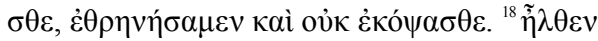

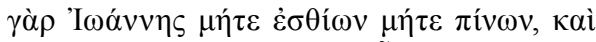

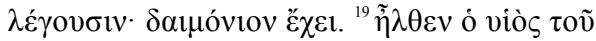

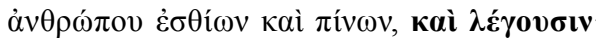

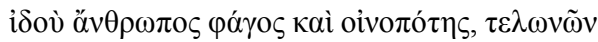

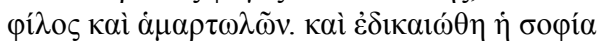

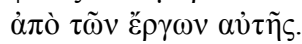

Mt 11,16 Lecz z kim mam porównać to pokolenie? Podobne jest do przebywających na rynku dzieci, które przymawiają swym rówieśnikom: ${ }^{17}$ „Przygrywaliśmy wam, a nie tańczyliście; biadaliśmy, a wyście nie zawodzili”. ${ }^{18}$ Przyszedł bowiem Jan: nie jadł ani nie pił, a oni mówią: „Zły duch go opętał”. ${ }^{19}$ Przyszedł Syn Człowieczy: je i pije. a oni mówią: „Oto żarłok i pijak, przyjaciel celników i grzeszników”. A jednak mądrość usprawiedliwiona jest przez swe czyny.

Niemal identyczna tradycja dotycząca reakcji biblijnego Izraela na misję Jana i Jezusa została przez Łukasza delikatnie zmodyfikowana. Łk 7,31 zdaje się ograniczać osąd Jezusa do pewnej grupy „ludzi tego pokolenia” ${ }^{44}$, podczas gdy Mateusz operuje twardym „to pokolenie” (Mt 11,16). Zmienia się również forma zaimka wskazującego z „oni” na „wy”, co w pewnym sensie zbliża Jezusa do adwersarzy Łk 7,34/Mt 11,18).

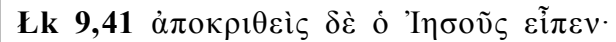

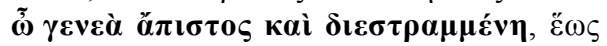

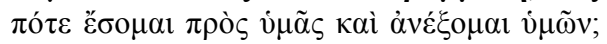

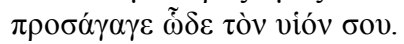

Lk 9,41 Na to Jezus rzekł: „O plemię niewierne i przewrotne! Jak długo jeszcze będę u was i będę was znosił? Przyprowadź tu swego syna!"

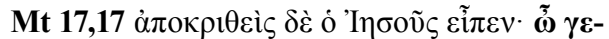

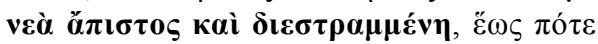

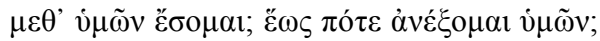

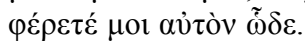

Mt 17,17 Na to Jezus odrzekł: „O plemię niewierne i przewrotne! Jak długo jeszcze mam być z wami; jak długo mam was cierpieć? Przyprowadźcie Mi go tutaj!”

W drugim tekście wypowiedź Jezusa jest identyczna w obydwu Ewangeliach, ale w tym wypadku jest oczywiste, że oskarżenie Mistrza przekazane przez

44 Już dawno temu zauważono, że rzeczownik ,ludzie” jest Łukaszowym dodatkiem i umożliwia mniej generalizujące zrozumienie tej frazy; zob. J.A. Fitzmyer, The Gospel according to Luke I-IX: Introduction, Translation, and Notes (AYB 28A; New Haven - London: Yale University Press 2008) 679. 
tradycję (Mk) jest kierowane do wszystkich, włączając uczniów Jezusa niepotrafiących zaradzić cierpieniu chłopca ( $\operatorname{~k~9,40/Mk~9,19/Mt~17,16)~}{ }^{45}$. Inaczej mówiąc, taka teologiczna optyka dobrze pasuje do redakcyjnego celu Łukasza. Identycznie postępuje on w przypadku źródła Q, jeśli stwierdzenie o grzeszności ludzkiej natury ma charakter ogólny (Mt 7,11 por. Łk 11,13).

\begin{tabular}{|c|c|}
\hline 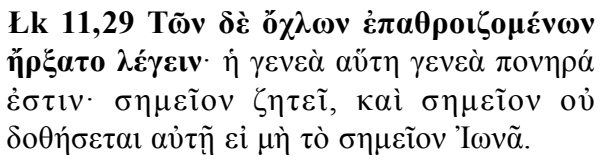 & 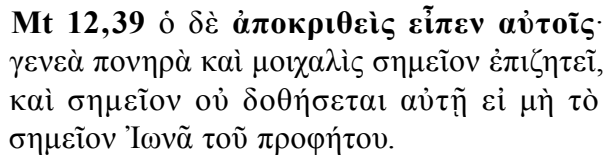 \\
\hline $\begin{array}{l}\text { Lk 11,29 A gdy thumy się gromadziły, zaczął } \\
\text { mówić: „To plemię jest plemieniem przewrot- } \\
\text { nym. Żąda znaku, ale żaden znak nie będzie } \\
\text { mu dany, prócz znaku Jonasza”. }\end{array}$ & $\begin{array}{l}\text { Mt 12,39 Lecz On im (uczonym w Piśmie } \\
\text { i faryzeuszom - w. 38) odpowiedzial: „Plemię } \\
\text { przewrotne i wiarołomne żąda znaku, ale } \\
\text { żaden znak nie będzie mu dany, prócz znaku } \\
\text { proroka Jonasza”. }\end{array}$ \\
\hline
\end{tabular}

W Łk 11,29 ewangelista wyraźnie zastosował ten sam redakcyjny zabieg, co w 3,7. Zamiast skupiać uwagę czytelnika na jednym czy drugim stronnictwie, wprowadza zdanie okolicznikowe o gromadzących się tłumach, które sprawia, że surowy epitet nabiera uniwersalnego charakteru ${ }^{46}$. Wszyscy żądają znaku i wszyscy zostaną w swoich oczekiwaniach zawiedzeni. Boże plany wobec Izraela przewidują bowiem tylko znak Jonasza. Obraz jest kontynuowany w w. 31-32, gdzie wspomina się o potępiającym wyroku królowej z południa i mieszkańców Niniwy.

Nawet w najostrzejszym fragmencie wypowiedzi przeciw faryzeuszom i innym słuchaczom, gdzie Mateusz wprost nazywa adwersarzy Jezusa „synami zabójców”

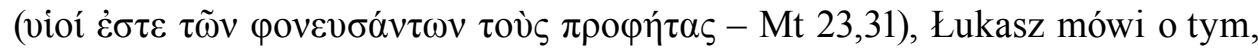

45 Przekonanie o ogólnym charakterze oskarżenia wyraża wielu egzegetów: „The criticism would seem to be addressed to the failed disciples as representatives of the generation". J. Nolland, Luke 9:21-18:34 (WBC 35B; Dallas: Word Incorporated 2002) 509; "It presently embodies the complete guilt of Israel". F. Bovon - H. Koester, Luke 1: A Commentary on the Gospel of Luke 1:1-9:50 (Minneapolis, MN: Fortress Press 2002) 387; ,[...] it seems to refer to the people present generally [...]", I.H. Marshall, The Gospel of Luke: A Commentary on the Greek Text (Exeter: Paternoster Press 1978) 391. Sens tej wypowiedzi ograniczają do uczniów Jezusa: H. Schürmann, Das Lukasevangelium: Erster Teil: Kommentar zu Kap. 1,1-9,50 (HTKNT 3/1; Freiburg: Herder 1969) 570, E.E. Ellis The Gospel of Luke (London: Nelson 1966; 2d ed.; London: Oliphants 1974) 144, F.W. Danker, Jesus and the New Age According to St. Luke: A Commentary on the Third Gospel (St. Louis: Clayton Publishing House 1972) 119.

46 Łukasz wielokrotnie przypomina swoim czytelnikom, że wokół Jezusa gromadzą się tłumy i otacza go sława skutecznego ewangelizatora, podkreślając tym samym Jego znaczenie: 4,14-15.22.32.37.42; 5,1; 6,17; zob. F. Bovon, Luke 2: A Commentary on the Gospel of Luke 9:51-19:27 (Hermeneia - CHCB) (ed. H. Koester) (Minneapolis, MN: Fortress Press 2013) 138, przyp. 18. Więcej na ten temat zob. K. Mielcarek, Jezus - Ewangelizator ubogich (Warszawa: AND 1994) 65-116. 
że budują oni grobowce tym, którzy zostali zabici, pochwalając tym samym czyny ojców (Łk 11,47-48). Po raz kolejny zatem łagodzi jednoznaczne tradycje Q/Mt. Konsekwentnie w Łk 11,51 za śmierć proroków i kapłanów odpowiadają bezpośrednio przodkowie, a nie słuchacze Jezusa, chociaż ich śmierć zostanie pomszczona na tym pokoleniu.

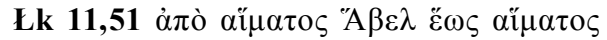

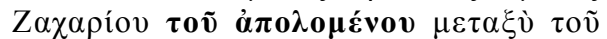

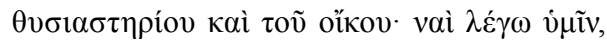

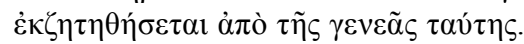

Lk 11,51 od krwi Abla aż do krwi Zachariasza, który zginąl między ołtarzem a przybytkiem. Tak, mówię wam, na tym plemieniu będzie pomszczona.
Mt 23,35 ö $\pi \omega \varsigma$ है $\lambda \theta \eta ฺ ~ \dot{\varepsilon} \varphi ’ \dot{v} \mu \tilde{\alpha} \varsigma \pi \tilde{\alpha} \nu \alpha \tilde{i} \mu \alpha$

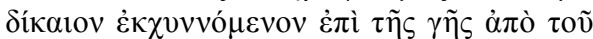

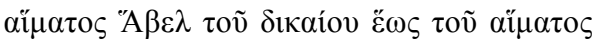

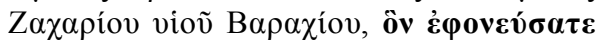

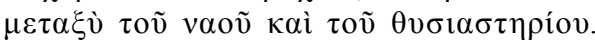

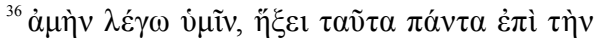
$\gamma \varepsilon v \varepsilon \grave{\alpha} \nu \tau \alpha \tilde{\tau} \tau \nu$.

Mt 23,35 Tak spadnie na was wszystka krew niewinna, przelana na ziemi, począwszy od krwi Abla sprawiedliwego aż do krwi Zachariasza, syna Barachiasza, którego zamordowaliście między przybytkiem a ołtarzem. ${ }^{36}$ Zaprawdę, powiadam wam: Przyjdzie to wszystko na to pokolenie.

Równie ważnym elementem odsłaniającym strategię Łukasza jest fragment stanowiący jego osobiste źródło (Łk 16,1-8 - SLk). Postawa nieuczciwego zarządcy zostaje bowiem użyta jako model postępowania polecany „synom światłości”, ponieważ synowie tego świata ( $\alpha i \omega ́ v)$ są roztropniejsi w postępowaniu

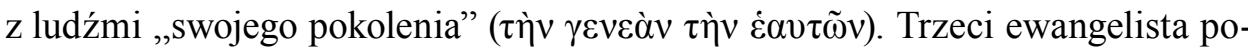
sługuje się zatem określeniem o najwyraźniej negatywnych konotacjach w Q/Mt w znacznie bardziej neutralny sposób, chociaż trudno odmówić mu także perspektywy ściśle historycznej, tzn. odniesienia do ludzi współczesnych ewangeliście, o trudnych doświadczeniach, o których wie on doskonale (powstanie żydowskie; por. Łk 17,25).

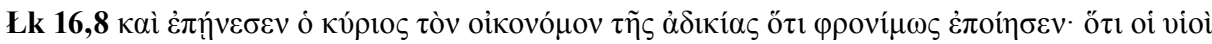

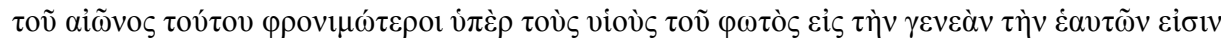

Lk 16,8 Pan pochwalił nieuczciwego rządcę, że roztropnie postąpił. Bo synowie tego świata roztropniejsi są w stosunkach z ludźmi podobnymi sobie niż synowie światłości (SLk).

Osobistym źródłem Łukasza jest również wypowiedź (Łk 17,25 - SLk), w której uzupełnia on tradycję eschatologiczną należącą do Q dotyczącą odrzucenia

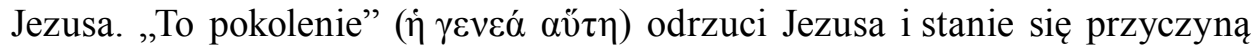
Jego cierpienia. Takie sformułowanie kolejny raz nie wskazuje jakiejś konkretnej grupy lub stronnictwa, lecz kieruje uwagę czytelnika ku ogólnej kondycji 
duchowej ludzi, którzy nie są w stanie przyjąć z wiarą obecnego wśród nich Mesjasza. W przedziwnym planie Boga ich postawa zostaje wpisana w historię zbawienia (por. Dz 3,12-21).

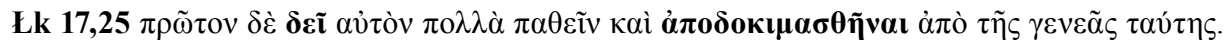

Lk 17,25 Wpierw jednak musi wiele wycierpieć i być odrzuconym przez to pokolenie (SLk).

Ważnym kontekstem tej wypowiedzi jest kolejna tradycja Q dotycząca paruzji. Jezus, zapowiadając nadchodzący sąd, stwierdza, że za dni Noego i Lota wszyscy prowadzili normalne życie i wszyscy $(\pi \tilde{\alpha} \varsigma)$ poza rodzinami wybranych, którzy opowiedzieli się za zbawczym planem Boga, zostali wytraceni (Łk 17,27-29). W ten sposób Łukasz ponownie kieruje apele nie do wybranej/napiętnowanej kasty przedstawicieli elit izraelskich, ale do każdego potencjalnego słuchacza ${ }^{47}$. Silny akcent na wszystkich w kontekście Bożego planu zbawienia przywołuje mowę św. Pawła na areopagu, gdzie zapewniał on Ateńczyków o powszech-

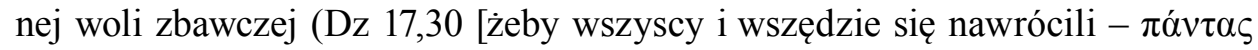
$\pi \alpha \nu \tau \alpha \chi 0 \tilde{v} \mu \varepsilon \tau \alpha \nu \circ \varepsilon \tilde{\imath}])$.

W podobnym duchu użyty został przekaz Marka, że „pokolenie to” doczeka się spełnienia Jezusowych obietnic. Także i w tym wypadku wskazanie dotyczące pokolenia odnosi się do wszystkich odbiorców, bez podziału na frakcje i grupy.

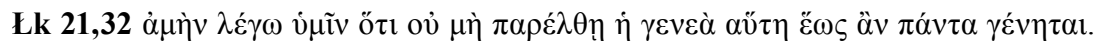

Lk 21,32 Zaprawdę, powiadam wam: Nie przeminie to pokolenie, aż się wszystko stanie $(\text { Mk 13,30; Mt 24,34) })^{48}$.

Ostatni fragment zawierający określenie „to pokolenie” znajduje się już w drugim tomie dzieła Łukaszowego. Został on wykorzystany przez ewangelistę w apelu apostoła Piotra kierowanym do zgromadzonych przy wieczerniku Żydów. Po wyjaśnieniu zjawisk towarzyszących zesłaniu Ducha Świętego (Dz 2,14-21) i jednoznacznym wskazaniu na Jezusa jako Pana i Mesjasza (Dz 2,22-36) słuchacze zwrócili się do apostoła z dramatycznym pytaniem: „Co mamy robić? (w. 37). W odpowiedzi usłyszeli zachętę do uwierzenia i przyjęcia chrztu w imię Jezusa, ponieważ zbawcze obietnice zostały przygotowane właśnie dla nich

47 Według R.C. Tannehilla wyliczone działania ,invite the hearer to feel the familiar, comfortable rhythm of life and recognize his involvement in it"; tenże, The Sword of His Mouth (Philadelphia/ Missoula, MT: Fortress/Scholars 1975) 119; tak też Nolland, Luke 9:21-18:34, 860.

48 Na temat tekstu Mt 24,34 powstał artykuł N.D. Nelsona, „«This Generation» in Matt 24:34: A Literary Critical Perspective", JETS 38/3(1995) 369-385. Autor słusznie zawęża Mateuszowe użycie wyrażenia w tym wersecie do ,an evil class of people who will oppose Jesus' disciples until the day he returns"; tamże, 385. Wcześniej, ale znacznie krócej, pisał na ten temat S.J. Kidder, „«This generation» in Matthew 24:34”, AUSS 21/3 (1983) 203-209. 
(w. 38-39). Została ona dodatkowo poparta wezwaniem, by ratować się ,z tego wykrzywionego pokolenia” [dosł. „z pokolenia tego skrzywienia”] ( $\sigma \omega ́ \theta \eta \tau \varepsilon$

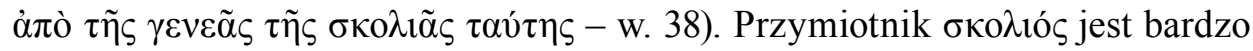
rzadki w Nowym Testamencie. Istnieją zaledwie cztery przypadki jego użycia, z czego dwa należą do dzieła Łukaszowego (Łk 3,5; Dz 2,40). Dwa pozostałe występują w listach Pawła (Flp 2,15) i Piotra (1 P 2,18) ${ }^{49}$.

Dz 2,40 W wielu też innych słowach dawał świadectwo i napominał: „Ratujcie się spośród tego przewrotnego pokolenia!".

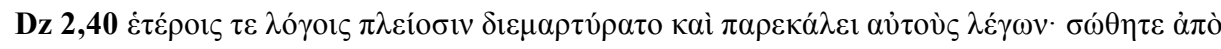

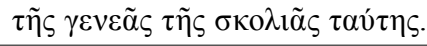

Tekst z Ewangelii jest de facto cytatem z Deutero-Izajasza (Iz 40,4) włożonym w usta Jana Chrzciciela przez wczesnochrześcijańską tradycję. Jednakże tylko Łukasz podaje ów cytat w rozszerzonej formie, z przymiotnikiem $\sigma \kappa \circ \lambda$ ıó (Łk 3,5). Zabieg redakcyjny wydaje się świadomy i tworzy ważny motyw powtórzony następnie na początku drugiego tomu dzieła. Wygnaniowy prorok językiem symboli zachęcał swoich pobratymców do nawrócenia, co autor Biblii

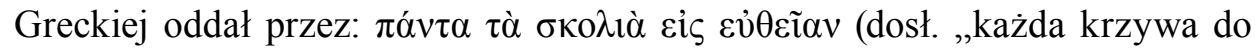
prostej") $)^{50}$, i co powtórzył trzeci ewangelista w orędziu Jana. Ten sam motyw Łukasz wykorzystał w pierwszej zachęcie nowo powstałego Kościoła, by „skrzy-

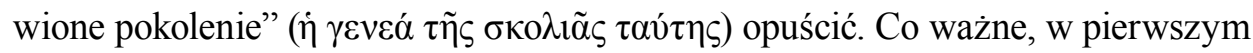
i w drugim przypadku perspektywa jest ponownie globalna. Wezwanie dotyczy wszystkich, by opowiedzieć się po stronie inicjatywy Boga i przyjąć zbawienie.

Podsumowując całą analizę tekstów dotyczących określenia „to pokolenie” i jemu pokrewnych, można stwierdzić, że autor Łk-Dz w sposób wyraźny redaguje swoją Ewangelię, by oskarżycielskie wypowiedzi Jana i Jezusa kierować do ogółu odbiorców. W ten sposób, nie wskazując nikogo z imienia, zachęca do nawrócenia wszystkich. Określenia ,plemię żmijowe” i „to pokolenie” nabierają przez to uniwersalnego, ale i nieco osłabionego znaczenia. Nie oznaczają już bowiem aktywnej złośliwości wobec Jezusa i Jego uczniów (Mk/Mt), ale raczej tych, którzy bez opowiedzenia się po stronie Ewangelii doświadczą duchowej śmierci. Tak rozumiane komentowane frazy nie odnoszą się już tylko

49 Zastosowanie przymiotnika w listach ma podobne odniesienie. Apostoł Paweł mówi w Flp 2,15

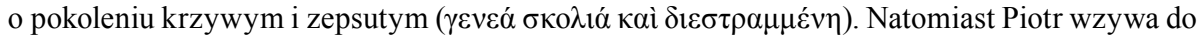
posłuszeństwa niewolników nawet wobec „skrzywionych” = nieuczciwych/niesprawiedliwych panów.

50 Zob. $B D A G, 930$ podaje dwa podstawowe znaczenia przymiotnika $\sigma \kappa o \lambda$ ıó $\varsigma$ : dosłowne: krzywy, wykrzywiony, przeciwny do prostego; i metaforyczne: moralnie skrzywiony, nieuczciwy, bezwzględny; podobnie inne słowniki. 
do współczesnych Jezusowi odbiorców, ale są apelem Zbawiciela do słuchaczy Ewangelii w każdym miejscu i czasie. Ich teologiczna perspektywa przypomina wyznanie Jezusa $z$ drogi krzyżowej skierowane do płaczących kobiet, należące do własnych źródeł ewangelisty: „Bo jeśli z zielonym drzewem to czynią, cóż się stanie z suchym?" (Łk 23,31).

Przeznaczeniem ,żmijowego pomiotu” jest śmierć, tak jak przeznaczeniem suchego drewna jest piec. Tylko wejście do społeczności uczniów Jezusa przez wiarę i chrzest może odwrócić ten wyrok (Dz 2,41-47; por. 3,26).

\section{Konkluzja}

Greckie określenie $\gamma \varepsilon v v \eta ́ \mu \alpha \tau \alpha ~ \dot{\varepsilon} \chi \imath \delta v \tilde{\omega} \nu$ ma bardzo bogate tło judaistyczne i grecko-rzymskie, wskazujące jednoznacznie na sferę zła, i to zła radykalnego. Jego wykorzystanie w ramach narracji ewangelicznej jest już jednak różne. Podczas gdy Mateusz akcentuje nim skrajne zaangażowanie faryzeuszy w opozycję wobec Jezusa, Łukasz pomija tego rodzaju wypowiedzi przypisywane Jezusowi, a napomnienie Jana Chrzciciela rozciąga na cały lud. Wymowa badanej frazy w trzeciej Ewangelii zostaje tym samym osłabiona, a uwaga czytelnika skierowana na ogólną kondycję grzeszności każdego z ludzi. Zabiegi redakcyjne Łukasza dotyczące epitetu o żmijach wpisują się dobrze w jego szerszą strategię akcentowania upadłego stanu ludzkiej natury wyrażonego między innymi przez określenie $\dot{\eta} \gamma \varepsilon v \varepsilon \grave{\alpha} \alpha u ̛ \tau \eta$. Dzięki temu ewangelista może jednoznacznie wskazać na potrzebę nawrócenia człowieka i na konieczność opowiedzenia się za Chrystusem.

Oczywiście badane terminy nie wyczerpują Łukaszowego obrazu upadłej natury ludzkiej. Z uwagi na wagę tej tematyki w znacznej mierze jest ona zresztą wspólna dla całości tradycji biblijnej. W przypadku Łukasza warte zbadania

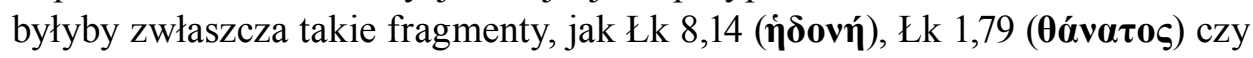

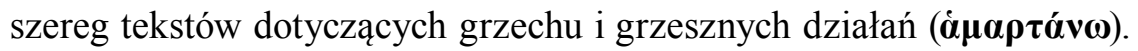

\section{Bibliografia}

Bauer, W. - Danker, F.W. - Arndt, W., A Greek-English Lexicon of the New Testament and Other Early Christian Literature. 3rd ed. (Chicago: University Press 2000).

Boice, J.M., The Gospel of Matthew (Grand Rapids, MI: Baker Books 2001).

Bovon, F. - Koester, H., Luke 1: A Commentary on the Gospel of Luke 1:19:50 (Hermeneia a Critical and Historical Commentary on the Bible; Minneapolis, MN: Fortress Press 2002).

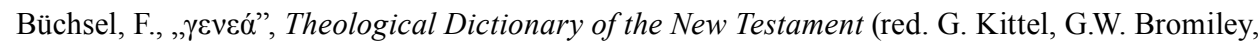
G. Friedrich; electronic ed. Grand Rapids, MI: Eerdmans 1964-c1976) I, 662-663. 
Carmignac, J., „Les elements historiques des «Hymnes» de Qumran”, Revue de Qumrân 2(1960) 205-222. Charlesworth, J.H., „John the Baptizer and the Dead Sea Scrolls”, The Bible and the Dead Sea Scrolls: The second Princeton Symposium on Judaism and Christian Origins. Volume three (red. J.H. Charlesworth) (Waco, Tx: Baylor University Press 2006).

Charlesworth, J.H., The Good and Evil Serpent: How a Universal Symbol Became Christianized (Yale: University Press 2010).

Charlesworth, J.H., Was John the Baptist a Member of the Qumran Community? Once More, Christian Origins and Hellenistic Judaism (red. S.E. Porter - A. Pitts; E-Books Online Collection: Brill 2013) 281-313, Chapter DOI: 10.1163/9789004236394_012 E-ISBN: 9789004236394.

Danker, F.W., Jesus and the New Age According to St. Luke: A Commentary on the Third Gospel (St. Louis: Clayton Publishing House 1972).

Davies, W.D. - Allison, D.C., A Critical and Exegetical Commentary on the Gospel According to Saint Matthew (London - New York: T\&T Clark International 2004).

Delcor, M., Les hymnes de Qumran (Hodayot): Texte hébreu, introduction, traduction, commentaire (Paris: Letouzey et Ane 1962).

Ellis, E.E., The Gospel of Luke (London: Nelson 1966; Oliphants 1974).

Fitzmyer, J.A., The Gospel according to Luke I-IX: Introduction, Translation, and Notes (AYB 28A) (New Haven; London: Yale University Press 2008).

García Martínez, F. - Tigchelaar, E., The Dead Sea Scrolls Study Edition (Translations) (Leiden - New York: Brill 1997-1998).

Hagner, D.A., Matthew 1-13 (WBC 33A; Dallas: Word Incorporated 2002).

Joüon, P. - Muraoka, T., A Grammar of Biblical Hebrew (SB 27; Rome: Editrice PIB 2006).

Keener, C.S., „«Brood of Vipers» (Matthew 3.7; 12.34; 23.33)”, Journal for the Study of the New Testament 2SA (2005) 3-11 (DOI: 10.1177/0142064X05057771).

Kidder, S.J., „«This generation» in Matthew 24:34”, Andrews University Seminary Studies 21/3 (1983) 203-209.

Knowles, M.P., „Serpents, scribes, and Pharisees”, Journal of Biblical Literature 133/1 (2014) 165-178.

Koehler, L. - Baumgartner, W. - Richardson, M.E.J. - Stamm, J.J., The Hebrew and Aramaic Lexicon of the Old Testament (electronic ed. Leiden-New York: Brill 1999 c1994-1996).

Liddell, H.G. - Scott, R. - Jones, H.S. - McKenzie, R., A Greek-English Lexicon (Oxford - New York: Clarendon Press; Oxford University Press 1996).

Lövestam, E., Jesus and «This Generation»: A New Testament Study (Stockholm: Almqvist \& Wiksell International 1995).

Marshall, I.H., The Gospel of Luke: A Commentary on the Greek Text (Exeter: Paternoster Press 1978).

Mędala, S., „List do arcykapłana z Qumran (4QMMT) a «jad żmijowy» faryzeuszów”, Collectanea Theologica 64/3 (1994) 47-72.

Mickiewicz, F., Ewangelia wedtug świętego Łukasza, rozdziały 1-11. Wstęp, przekład z oryginału, komentarz (Nowy Komentarz Biblijny III/1; Częstochowa: Edycja Świętego Pawła 2011).

Mielcarek, K., Jezus - Ewangelizator ubogich (Warszawa: AND 1994).

Milik, J.T., „4Q Visions de “Amram et un citation d'Origene”, RB 79 (1972) 81-82.

Moessner, D.P. „The «Leaven of the Pharisees» and «this generation»: Israel's rejection of Jesus according to Luke", Journal for the Study of the New Testament 34 (1988) 21-46.

Muchowski, P., Rękopisy znad Morza Martwego. Qumran, Wadi Murabba'at i Nachal Chewer (Kraków: Enigma Press 2000). 
Nelson, N.D., „«This Generation» in Matt 24:34: A Literary Critical Perspective”, Journal of the Evangelical Theological Society 38/3 (1995) 369-385.

Nolland, J., The Gospel of Matthew: A Commentary on the Greek Text (Grand Rapids, MI; Carlisle: Eerdmans; Paternoster Press 2005).

Paciorek, A., Ewangelia wedtug świętego Mateusza. Rozdziały 1-11 (Nowy Komentarz Biblijny NT 1/1; Częstochowa: Edycja Świętego Pawła 2005).

Rakocy, W., Obraz i funkcja faryzeuszy w dziele. Lukaszowym (Łk-Dz): studium literacko-teologiczne (Lublin: Redakcja Wydawnictw KUL 2000).

Schürmann, H., Das Lukasevangelium: Erster Teil: Kommentar zu Kap. 1, 1-9, 50 (HTKNT 3/1; Freiburg: Herder 1969).

Simonetti, M., Matthew 14-28 (Ancient Christian Commentary on Scripture. New Testament 1b; Downers Grove, Ill: InterVarsity Press 2002).

Tannehill, R.C., The Sword of His Mouth (Philadelphia/Missoula, MT: Fortress/Scholars 1975). Wise, M.O. - Abegg, jr. M.G. - Cook, E.M., The Dead Sea Scrolls. A New English Translation (San Francisco, Ca: Harper Collins 1996, 2005, electronic edition). 